\title{
カメラに対する操作と撮影による写真のブレとの関係 に関する考察*
}

\section{加藤麻樹 $* *$, 石田敏郎 ${ }^{* * *}$}

A camera, while it is being used, is constantly subjectd to vibration by its users. That vibration, the subject of this paper, was studied in two experiments. One was the measurement of the bias size of a target in a picture. Three types of cameras were used in this experiment. The pictures taken by subjects had a target image. They were measured for bias by normal-photography and by timer-photography. The other was an analysis of oscillation sampled from the cameras. Two types of cameras were used in this experiment. Each of the cameras had three dimensional accelerometers on top of it and a manometer on its shutter button. When a subject pushes the manometer to take a picture, the oscillations were determined by the accelerometers.

From these experiments, two causes of camera vibration may be distinguished, as follows: One is camera vibration caused by microvibration on the surface of the subject's hands and physiological tremor on forearm. This oscillation is about $4.0 \mathrm{~Hz}$. The other is caused by the subject's pushing action against the shutter button. This oscillation is about $2.0 \mathrm{~Hz}$. This kind of vibration occurs because the user's pressure on the shutter button is too strong to keep the camera fixed. The results show that most of the vibration of cameras is caused by manipulation against the camera.

\footnotetext{
一眼レフカメラの操作性において問題となる手ブレに関する研究として, その要因について検討し た. 実験 1 ではシャッターボタンに圧力計を取りつけた 3 種類の一眼レフカメラを用いて, 通常撮影 とタイマーを用いた撮影を行い, このとき生じた写真上のブレ量を計測した. 実験 2 では 2 種類の一 眼レフカメラに, 3 軸方向の加速度計と, シャッターボタン上に圧力計を取りつけ, 撮影に要する 2 秒間の振動波形を取得し，これをFFT 解析した。

撮影時に生じるカメラの振動には, カメラの内部振動とユーザによる外部振動があるが, 外部振動 について行った実験結果を要約すると以下のとおりである.すなわち, (1)身体表面に生じている 4 8 $\mathrm{Hz}$ の microvibration, および手関節と时関節における生理的振戦を主な要因とする振動が直接カメ ラに伝達される. (2)シャッターを押す操作を要因とする $2.0 \mathrm{~Hz}$ 以下の振動がカメラに伝達される. (3) ユーザのシャッター操作は過剩になされることが多く, 個人差が大きい. 以上の点から, 写真撮影時 に生じるカメラの振動は, $8.0 \mathrm{~Hz}$ 以下の低周波数帯域のものが主であり, ユーザのカメラに対する操 作そのものによってもたらされることが明らかとなった。

(キーワード：振動波形, microvibration, 写真撮影, 操作)
}

* 1995 年 2 月 27 日受付

** 早稲田大学 理工学総合研究センター Advanced Research Center for Sci. and Eng., Waseda Univ.

*** 早稲田大学 人間科学部 School of Human Sciences, Waseda Univ.

\section{1. はじめに}

従来, 専門家やマニアを主な対象としていた一眼レ フカメラは, 近年, 電子技術の採用による機能の自動 
化が進み, ユーザ層は一般家庭にも広がってきた。自 動露出機構 (Auto Exposure) は, 撮影に必要とされ る光量を得るために周囲の明るさを検知し, 絞りを調 節する。 また, 自動焦点機構 (Auto Focus) は, 被写 体に対する焦点距離を調節する。こうした機構の採用 により，カメラの使用経験の浅いユーザにも美しい写 真が撮影できるようになった。しかし，これらの調節 が適切に行われるようになったことで, 撮影において 相対的に目立ってきた問題が “手ブレ”である. “手ブ レ”とは, カメラの保持やシャッターの押し方がわる く, シャッターの開いている間にカメラを微動させる こどである。

写真撮影時にカメラに生じる振動には, 大きく分け て 2 種類がある. ひとつはカメラ内部においてシャッ タ一幕とミラーが動くことにより生じる内部振動であ り，スペックル写真法により確認することができる. 内部振動は機種により差があるが，いずれも露出時間 が $1 / 60$ 秒のときの発生率が高く, $1 / 2$ 秒以上あるいは $1 / 500$ 秒以下の場合は振動の発生率は小さい2).

もうひとつはカメラを手に保持して撮影を行った場 合のユーザによる外部振動である、ユーザ, すなわち 人間によってもたらされる振動には, 人間の生理的な 働きによって生じる振動と, 人間が随意的に動くこと によって生じる振動とがある. 前者は温血動物の身体 表面に常に生じている microvibration とよばれる振 動が主なものである ${ }^{3,7}$. Microvibration には $\theta(4 \sim 8$ $\mathrm{Hz}), \alpha(8 \sim 13 \mathrm{~Hz}), \beta(13 \sim 20 \mathrm{~Hz})$ の 3 周波数帯域 があり，自律神経系が関連しているといわれる。また, 身体内部の振動として, 荷重時の前腕に直接関連する 関節の生理的振動が考えられる ${ }^{6}$. 後者はカメラの保 持姿勢を維持するための体の微動と, シャッター操作 のために右手の人差し指でシャッターを押す際の圧力 によるものである，スティルカメラを用いて写真を撮 影する場合にはシャッターを押す操作が必要であるた め, この振動はカメラの構造上, 必然的に生じる振動 であるといえる。

勝浦は, ビデオカメラの望ましい重量を(最大筋力 $\times$ $10 \%$-体重 $\times 2.2 \%) \mathrm{kg}$ 以下とすると同時に, グリッ プ位置, 保持方法について望ましい形状を提唱してお り,ビデオカメラの振動を削隇することが可能である としている4).これに対しスティルカメラの “手ブレ” に関する研究は, 現在までほとんどみられない.そこ で本研究では, スティルカメラ, 特に近年の普及が著 しい一眼レフカメラの “手ブレ”を研究対象とし, “手 ブレ”に影響を与える要因を明らかにすることを目的 とする.

\section{2. “手ブレ”の評価}

本研究ではスティルカメラの “手ブレ”を評価する にあたり，2つの方法を用いた。 まず，図 1 に示す被 写体を撮影した写真を拡大し, 計測点 $\mathrm{a}-\mathrm{b}$ 間の距離を $100 \%$ とした。このときの各計測点 $\mathrm{a}, \mathrm{b}, \mathrm{c}, \mathrm{d}, \mathrm{e} の$ 軌跡を測り, 平均值の割合を写真上に生じるブレ量と した. 次に, シャッター操作時にカメラ本体に生じる 振動を, 上下, 左右, 前後方向の 3 方向について, 最 大 $5 \mathrm{G}$ まで計測可能な加速度計を用いてシャッター操 作の時点を中心に 2 秒間計測し，これをカメラ本体に 生じるブレ量とした. シャッター操作については, シ ヤッターにかけられる右手人差し指の圧力を圧力計を 用いて計測した. 同時に, 圧力計の出力がキャリブレ ーションレンジ内の最大值を示す時点をシャッター操 作の時点とみなし, 上記の加速度計出力を撮影時の振 動として記録した.

\section{3. 実験方法}

本研究では 2 つの実験を行った。実験 1 では, 写真 上に生じるブレ量とシャッター操作の圧力との相関を 調べた. 実験 2 では, カメラに生じるブレ量をスペク トル解析することにより，“手ブレ”がカメラに与える 影響を調べた。双方の実験で使用したカメラの物理的 特徴を表 1 に示す。

\section{3-1. 実 験 1}

3 機種の一眼レフカメラ $(\mathrm{A}, \mathrm{B}, \mathrm{C})$ を使用し, 各 シャッター部には圧力計（PS-2 KASF 3）を装着し た. 被写体の各計測点は LEDにより発光させ, カメラ と被写体との距離は $1.5 \mathrm{~m}$ とした.このとき被写体の

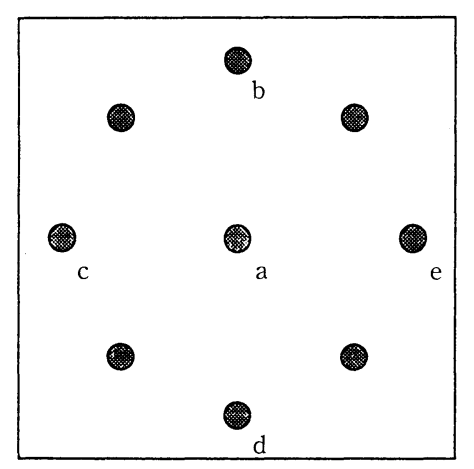

図 1 被写体

Fig. 1 Target. 
表 1 使用カメラの性能

Tab. 1 Specification of each camera.

\begin{tabular}{lrrrrr}
\hline \multicolumn{1}{c}{ 機 種 } & A & B & C & D & E \\
\hline ボディ幅 & $138 \mathrm{~mm}$ & $148 \mathrm{~mm}$ & $149 \mathrm{~mm}$ & $147 \mathrm{~mm}$ & $136 \mathrm{~mm}$ \\
ボディ高さ & $92 \mathrm{~mm}$ & $108 \mathrm{~mm}$ & $102 \mathrm{~mm}$ & $97 \mathrm{~mm}$ & $88 \mathrm{~mm}$ \\
ボディ奥行 & $52 \mathrm{~mm}$ & $68 \mathrm{~mm}$ & $55 \mathrm{~mm}$ & $48 \mathrm{~mm}$ & $53 \mathrm{~mm}$ \\
重さ (レンズ含む) & $842 \mathrm{~g}$ & $1234 \mathrm{~g}$ & $1063 \mathrm{~g}$ & $1117 \mathrm{~g}$ & $655 \mathrm{~g}$ \\
セルフタイマ & $10 \mathrm{sec}$ & $10 \mathrm{sec}$ & $10 \mathrm{sec}$ & $10 \mathrm{sec}$ & $10 \mathrm{sec}$ \\
\hline
\end{tabular}

レンズはすべて標準 $50 \mathrm{~mm}$ ，フィルムは $35 \mathrm{~mm}$ を使用

高さは，その中心を被験者の立位眼高にあわせた。被 験者はカメラを自由に構えたうえで, 被験者自身のシ ヤッター操作 (通常撮影) と，カメラを保持した夕イ マー撮影（タイマー撮影）の 2 種類の作業を各 2 回ず つ行った.

撮影時の露出時間は, 内部振動の発生率が低い露出 時間として, $1 / 2$ 秒に統一した。焦点距離は $1.5 \mathrm{~m}$ に固 定し, 露出は自動露出 (Auto Exposure：AE) を使用 した. 被験者は右利きの男子大学生 17 名, 女子大学生 19 名の計 36 名, 平均年齢 21.3 歳であった.

\section{3-2. 実 験 2}

実験システムを図 2 に示す。ここでは, 撮影時に生 じる振動のみを抽出する必要があるため, 自動フィル ム巻取り（Auto Rewind）機能のないマニュアル操作 による巻取りを行う機種を用いて実験を行った。まず 2 機種の一眼レフカメラ $(\mathrm{D}, \mathrm{E})$ を使用し, ファイン ダ上部に，カメラの上下，左右，前後方向に対して金 属製のステーにマウントした加速度計 (AS 5-GAS) を 取りつけた。さらに, シャッター部に圧力計 (PS-2 KASF 3)を取りつけ, カメラからの出力を計 4 チャン ネル取得した。被験者はこのカメラを用い, 中心を被
験者の立位眼高の高さにした被写体を, 焦点距離固定, 露出時間 $1 / 2$ 秒, 露出は $\mathrm{AE}$ 使用の状態で, 各カメラ につき 3 回ずつ撮影を行った. なお, カメラから被写 体までの距離は $2 \mathrm{~m}$ に固定した。撮影に要した 2 秒間 の振動をサンプリングし, これを波形解析の対象とし た. 被験者は男子大学生 20 名, 女子大学生 25 名の計 45 名, 平均年齢 22.5 歳であった. このうち一眼レフカ メラの使用経験のあるものは 13 名であった。

また比較実験として, 三脚およびタイマーを使用し た固定撮影を同じ条件で行った。

実験 2 のデー夕（3 方向の振動波形）は FFT にか け, その振動周波数のピークについて解析した.さら に, 各被験者のパワースペクトルのピーク周波数を抽 出した。

\section{4. 結 果}

\section{4-1. 実 験 1}

通常撮影により写真に生じたブレ量の度数分布を図 3 に, タイマー撮影により写真に生じたブレ量の度数 分布を図 4 に示す.いずれも縦軸は度数, 横軸はブレ

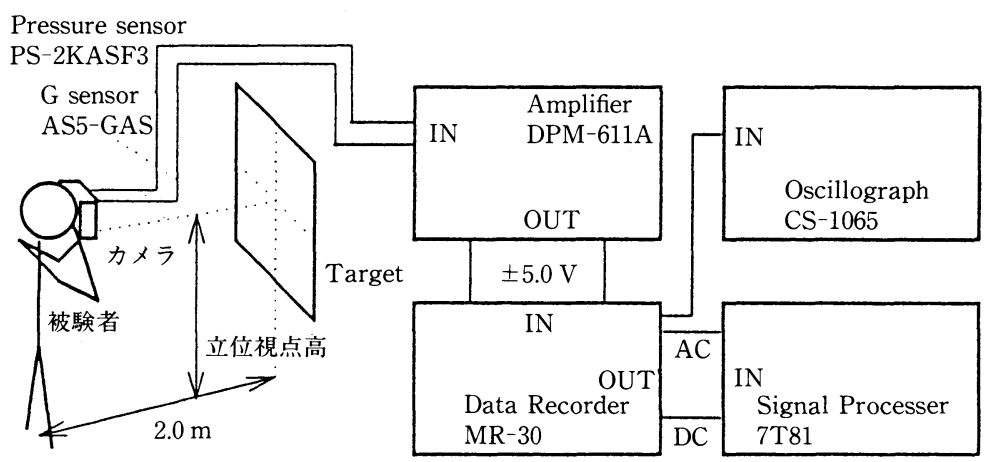

図 2 実験システム

Fig. 2 Experiment system. 


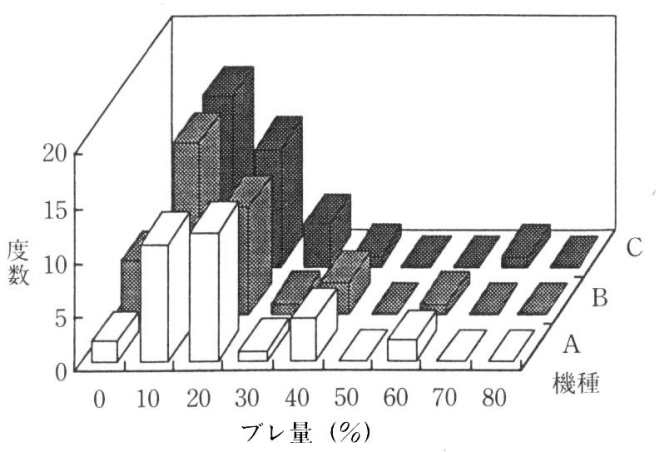

図 3 通常撮影による写真のブレ量

Fig. 3 Bias on normal-photography.

量, 前後軸はカメラの機種を表している，通常撮影に おいて最もブレ量の頻度が高かったのは 10〜20\%の 範囲であったが，タイマー撮影では 0 ～10\%，㧍よび 10〜20\%の範囲にブレ量の頻度が分散した。また， 20〜30\%の範囲に扔いては通常撮影で頻度が高く, 夕 イマー撮影ではほとんどみられなかった。

通常撮影（図 3 ）において, 被験者が撮影時にシャ ッターボタンにかけたシャッター圧力を被験者ごとに 図 5 に示す。さらに，各被験者によるシャッター圧力 に関する度数分布を図 6 に示す。このとき最も頻度が 高かったのは 500 1000 gf $/ \mathrm{cm}^{2}$ の範囲であり, 次に $1000 \sim 1500 \mathrm{gf} / \mathrm{cm}^{2}, 1500 \sim 2000 \mathrm{gf} / \mathrm{cm}^{2}$ の範囲が続い た。シャッターを扔ろすために必要な圧力は，カメラ $\mathrm{A}$ で $375 \mathrm{gf} / \mathrm{cm}^{2}$, カメラ Bで $333 \mathrm{gf} / \mathrm{cm}^{2}$, カメラCで $349 \mathrm{gf} / \mathrm{cm}^{2}$ であった。つまり上記の結果では，ほとん どの被験者がシャッターボタンに 2 倍以上の圧力をか

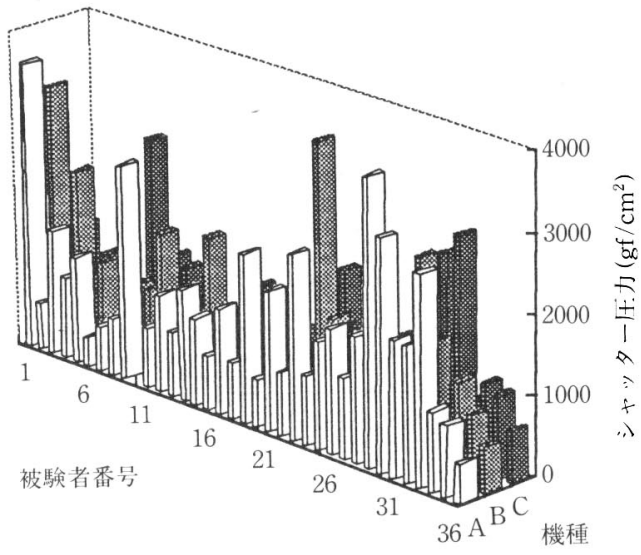

図 5 シャッターボタンにかけられる压力

Fig. 5 Pressure on the shutter-button of each camera.

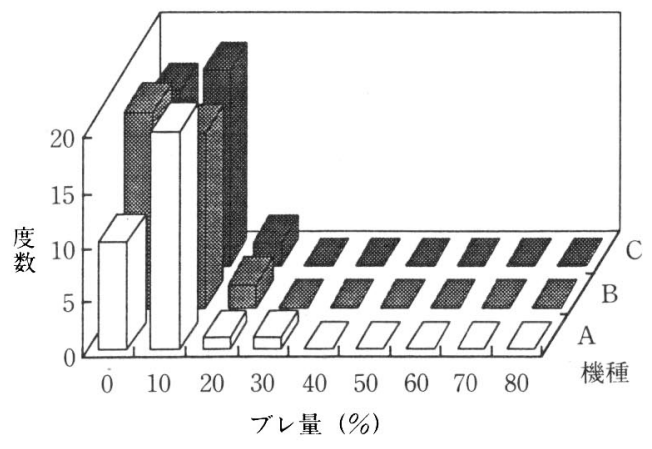

図4 タイマー撮影による写真のブレ量

Fig. 4 Bias on timer-photography.

けていたといえる.

機種ごとの手ブレの特性の差を調べるために，シャ ッターにかけられる圧力, 通常撮影におけるブレ量, およびタイマー撮影におけるブレ量のそれぞれについ て，二元配置による分散分析を行った。シャッター圧 力の個人差については，統計的に有意差がみられたこ とから，シャッターの押し方には個人差が影響するこ とがわかった $(\mathrm{F}=2.52, \mathrm{df}=35, \mathrm{p}<0.05)$.また，力 メラの機種間については，統計的に有意な差がみられ なかったことから，カメラ側の要因がシャッターにか けられる圧力に与える影響はあまり大きいものではな かったといえる.

通常撮影および夕イマー撮影のブレ量に関しては, カメラの機種間に統計的有意差は認められなかった。 個人差については通常撮影の場合に統計的有意差が認 められたが $(\mathrm{F}=3.10, \mathrm{df}=35, \mathrm{p}<0.05)$, 夕イマー撮 影の場合は有意差がみられなかった。

次に通常撮影時の写真上に生じるブレ量と，シャッ

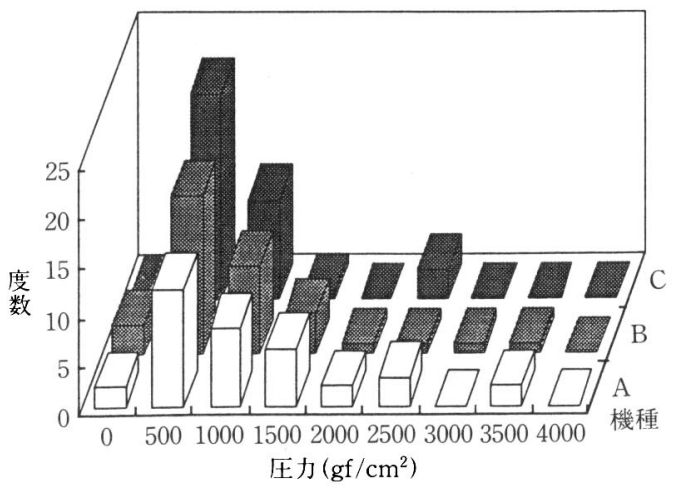

図 6 シャッターボタンにかけられる圧力の度数分布

Fig. 6 Pressure on the shutter-button. 


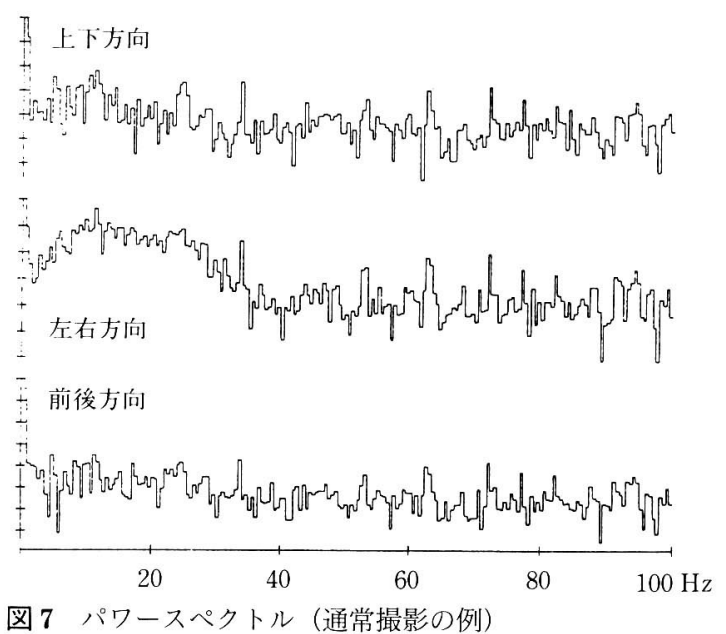

Fig. 7 A sample of power-spectrum by normal-photography.

ターにかけられる圧力との相関係数を求めた結果，力 メラ Aが 0.64 , カメラBが 0.70 , カメラCが 0.60 で あった.いずれの場合も 0.60 以上の值が得られ，シャ ッターにかけられる圧力とブレ量との間にはやや高い 相関関係があると認められた。

通常撮影時の写真に生じるブレ量とタイマー撮影時 の写真に生じるブレ量に関しては, 双方の撮影方法に ついて統計的に有意差があることが認められた（ $\mathrm{t}=$ 8.51, $\mathrm{df}=103, \mathrm{p}<0.01)$.

\section{4-2. 実 験 2}

カメラに取りつけた加速度計より得られる振動波形 をFFTにかけ，パワースペクトル化した，例として， カメラDを用いた場合のパワースペクトルを図 7 に, 三脚とタイマーを用いた比較実験のパワースペクトル を図 8 に示す。図 7 は一眼レフカメラの使用経験のあ

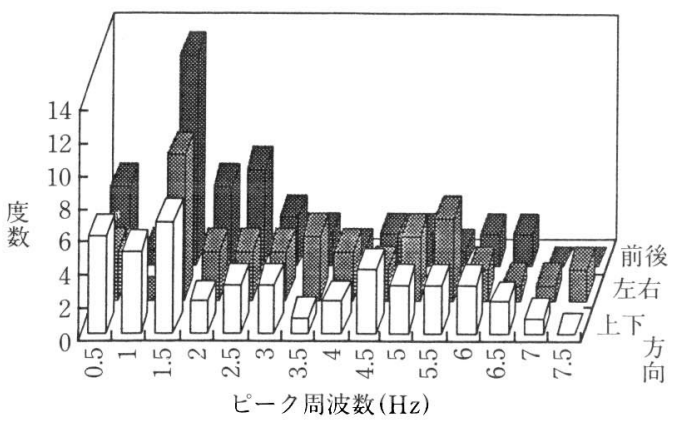

図 9 カメラDによるピーク周波数の度数分布

Fig. 9 Peak frequency of power-spectrum by camera D.

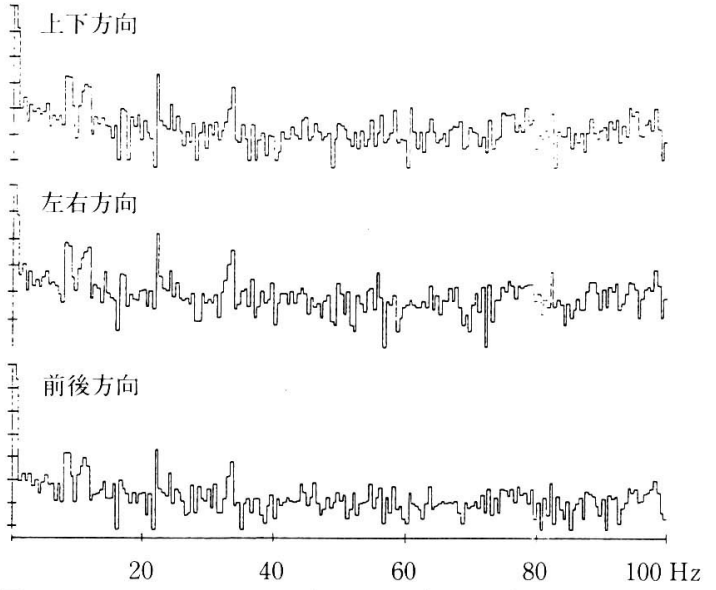

図 8 パワースペクトル（タイマー撮影の例）

Fig. 8 A sample of power-spectrum by timer-photography.

る被験者による撮影時のパワースペクトルであり，左 右方向におけるピークの形成のしかたが特徽的であっ た。これに対して三脚撮影（図 8) では，スペクトル のピークが平均化しており，通常撮影との差がカメラ 上の振動としても顕著に現れたといえる.

各被験者のパワースペクトルのなかで最も高いピー クを形成している周波数帯域を抽出し, 度数分布にま

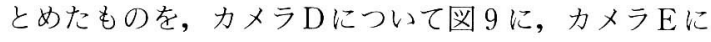
ついて図 10 に示す.いずれも縦軸は度数, 横軸はピー ク周波数を示し，前後軸は計測した振動の方向を表し ている.上下方向の振動は, カメラ D, Eいずれの場合 も $1.5 \mathrm{~Hz}$ 以下抽び $4.5 \mathrm{~Hz}$ 付近にピーク周波数が 集中した. 左右方向の振動は，カメラDの場合には 1.5 $\mathrm{Hz}$ 付近にピーク周波数が集中したが，力メラ $\mathrm{E} の$ 場 合には $0.5 \mathrm{~Hz}$ 付近および $5.0 \mathrm{~Hz}$ 付近に分散するの が特徴であった．前後方向の振動にも左右方向での機

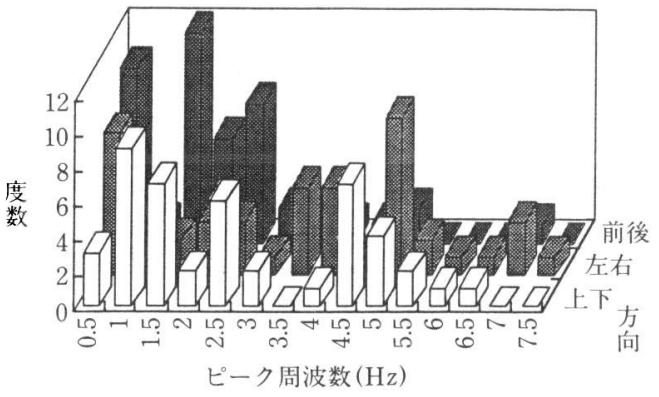

図 10 カメラ Eによるピーク周波数の度数分布

Fig. 10 Peak frequency of power-spectrum by camera E. 
種間の差と似た傾向がみられ，カメラ Dでは $1.5 \mathrm{~Hz}$ 付近にピーク周波数が集中したが，カメラ Eでは 2.5 $\mathrm{Hz}$ 以下に分散した. ピーク周波数を全体的にみると，

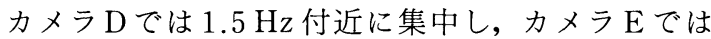
$0.5 \sim 2.5 \mathrm{~Hz}$ の幅広い範囲にデータが分散したといえ る.

各方向別の振動の差異を調べるため，カメラごとに 振動方向別のピーク周波数について，二元配置による 分散分析を行った．個人差については，いずれのカメ ラの場合も実験 1 のとき同椂に統計的な有意差が認 められた（カメラ D : F = 2.02, $\mathrm{df}=44, \mathrm{p}<0.05$, カ メラ $\mathrm{E}: \mathrm{F}=2.28, \mathrm{df}=44, \mathrm{p}<0.05)$.また, 機種間に おいても統計的有意差が認められた（カメラ D : F= $3.76, \mathrm{df}=1, \mathrm{p}<0.05$, カメラ $\mathrm{E}: \mathrm{F}=11.59, \mathrm{df}=1$, $\mathrm{p}<0.05)$.

両カメラの各方向における振動のピーク周波数に関 する機種間の差の有無を調べたが, 方向別にみた場合, 有意差が現れたのは前後方向における振動のみであっ た $(\mathrm{t}=1.72, \mathrm{df}=44, \mathrm{p}<0.05)$.つまり前後方向の振 動については，機種ごとの特性が影響したといえる。

\section{5. 考 察}

実験 1 において通常の撮影方法とタイマーによる撮 影方法の比較を行ったが，写真上に生じるブレ量は前 者のほうが大きい場合が多い. 双方の撮影方法の違い はシャッターボタンを被験者が押すか押さないかであ り，シャッター操作が “手ブレ”に大きく影響してい るといえる。シャッターボタンにかけられるべき圧力 は, 各カメラともに $350 \mathrm{gf} / \mathrm{cm}^{2}$ 前後で十分であるにも かかわらず，被験者のほとんどは 2 倍以上の圧力を加 えており，過剩なシャッター操作がカメラ本体に余分 な振動を生じさせていると思われる. 写真上に生じる ブレ量とシャッターボタンにかけられる圧力との相関 係数が, いずれのカメラの場合も高い值を示している ことからも, 両者の間になんらかの関係があることが 示唆される.この傾向はカメラの機種の違いによらず, いずれの機種の場合にも常に生じていることから，ユ 一ザがカメラを常に正しい方法で操作しているとは限 らないといえる.すなわち, ブレ量は個人ごとの特性, つまりシャッターの押し方を要因として変化すると思 われる。

これに対して実験 2 では, カメラ本体に生じる振動 は, カメラの機種による特性が異なる場合があること が示されている.すなわち，カメラDを用いた場合と カメラ $\mathrm{E}$ を用いた場合とで，ピーク周波数の度数分布 が異なっている.カメラDではすべての方向において
一定の周波数帯域にピーク周波数が集中するのに対し て,カメラ Eではかなりピーク周波数が分散してい る. 形状的には両カメラに大きな相違点はないが, 重 量についてはカメラDはカメラEの約 2 倍である.今 回の実験では使用カメラが 2 機種であるため結論づけ ることはできないが, カメラにある程度の重量をもた せることによって, 撮影時に生じる振動の周波数が一 部分に集中すると思われる. 実験結果ではカメラDの ときに $2.5 \mathrm{~Hz}$ 以上の周波数成分が減少している。こ の周波数帯域は上述した microvibration の $\theta$ 波, お よび関節の震えの成分に近似しており, 筋負担とこれ らの振動との間に負の因果関係が存在することを示唆 している.よって筋負担が少ないカメラ Eの場合は, 振動が抑制されずに出現したのではないかと考えられ る.

振動を全体的にみると, 機種間の相違は認められる が，いずれも大半のピーク周波数は低周波数帯域 $(6.0$ $\mathrm{Hz}$ 以下)に集中している. したがって, 撮影中の振動 のほとんどが内部振動と比較して遅い被験者による動 作を要因としていることが推察される.FFT の結果の うち, 三脚を用いた撮影では振動パワースペクトルは 平滑となり, 通常撮影のパワースペクトルは明らかに ユーザを要因とすると思われるピークを形成している。 両者の比較から “手ブレ” の最も大きな要因は, ユー ザによる低周波帯域の振動であるといえよう。

\section{6. まとめ}

本研究において得られた結果より, 撮影時に“手ブ レ”を発生させる一連の構造を, 以下のような流れに まとめる.まず, カメラをホールドする際, microvibration の $\theta$ 波, および手関節, 时関節における生理的振 戦を主な要因とすると思われるユーザ側の不随意的な $6.0 \mathrm{~Hz}$ 以下の振動が, 接触部からカメラに直接伝わ る.さらに, 撮影に際してシャッターボタンを押す操 作を行うことで, 操作に必要とする時間, つまりカメ ラに圧力が加えられる時間を 1 周期とする低周波数帯 域 $(2.0 \mathrm{~Hz}$ 以下) の振動が新たに生じる.このときの 操作がカメラを最初にホールドした位置からずらして しまう. シャッター操作直後よりシャッタースピード 分の時間にはシャッターが開き, フィルムが感光して いるため, 相対的に被写体とカメラの固定された関係 が崩れた状態で映像が記録される. 結果的に写真上で は“ブレ”が生じ, “手ブレ”という評価が下される. 先に述べたように，写真を撮影する際にカメラに生 じる振動は, シャッター幕とミラーが開くことによっ て生じる内部振動と, ユーザがカメラを手に持つこと 
で与えられる外部振動との 2 種類があり, 今回の研究 では後者のユーザによる外部振動をその対象としたが, その振動特性は機種ごとに異なる傾向があることが示 唆された.また, これらの振動の要因としては“手に 持つ”, “シャッターを押す” という撮影に必要不可欠 な人間の動きがあげられるため, 現時点ではこれらの “手ブレ” 発生の直接的要因を除去することは難しい. これらの改善のためには外部振動を明確に分離したう えで，その構成要素を特定することが必要である。

今後, 写真撮影時の “手ブレ” のみならず, 機器を 操作する際のユーザの振動発生のメカニズムを定量的 に評価するモデルの構築には, 上記の直接的振動要因 に影響を与える間接的な要因を, ユーザの身体的特性 の面から明確化する必要がある。

\section{参考文献}

1）上野千鶴子ほか：カメラ事典 新版,ペリカン社, 1985.

2) H. Kondo, H. Imazeki, T. Tsuruta : Measurement of Image Blur Due to Interisic Vibration of Camera Body by Applying Speckle Photography, Journal of Applied Photographic Engineering, 9(5), 1983.

3）宮田 洋, 藤澤 清, 柿木昇治: 生理心理学, 朝倉書店, $118 \sim 112,1985$.

4) 勝浦哲夫 : ビデオカメラの人間工学, 人間工学, 第 26 巻特別号, 1990 .

5）写真工業出版社編：カメラレンズ百科, 写真工 業出版社, 1986.

6) James R. Fox, James E. Randall : Relationship between forearm tremor and the biceps electromyogram, Journal of Applied Physiology, 29(1), 103 108, 1970.

7) 尾崎俊行, 稲永和豊, 山岡 淳: Microvibration 生理学的意義, 臨床的意義, 心理学的意義, 臨床脳波, $14(1), 1 \sim 23,1972$.

8）加藤麻樹, 石田敏郎：一眼レフカメラの操作性 に関する一研究, 日本人間工学会第 22 回関東支部 大会講演集，38，1992. 